\title{
A PULSÃO DA ERRÂNCIA, O DEVIR-MULHER E A POTÊNCIA DA ARTE EM A DOCE CANÇÃO DE CAETANA ${ }^{1}$
}

Roniê Rodrigues da Silva (UERN)

Resumo: Este trabalho objetiva realizar uma leitura crítica do romance A doce canção de Caetana, da escritora contemporânea Nélida Piñon, associando o tema da errância à noção do devir-mulher e à ideia de potência representadas pela protagonista Caetana, uma fracassada atriz mambembe que perambula pelo interior do Brasil como herdeira de uma arte funâmbula, legatária de uma vida de ciganos, e que aparece na obra nelidiana intercambiando seu fazer artístico por ovos ou galinhas, a fim de sobreviver. Experienciando o que Michel Maffesoli (2001) denomina por efervescência dionisíaca, à parte de uma indústria cultural do entretenimento, é possível afirmar que Caetana e sua trupe manifestam o desejo por formas de subjetivação que escapam à ordem imperante das instituições de poder, encenando a aventura da existência por uma vivência anômica caracterizada pela desterritorialização, pela movência constante, e pela possibilidade de devir, conforme a discussão desenvolvida por Gilles Deleuze e Félix Guattari (1997).

Palavras-chave: Literatura Brasileira; Nélida Piñon; Errância; Devir; Potência.

\begin{abstract}
This paper aims to do a critical analysis of the novel $A$ doce canção de Caetana (Caetana's Sweet Song), by the contemporary writer Nélida Piñon, relating the wanderer theme to the notion of becomingwoman and the idea of potency, through the representation of the protagonist Caetana. She is a failed mambembe actress (actress of a traveling theater) who wanders throughout the interior of Brazil as the heiress of a funambulist art. She is a legatee of a gypsy family that appears in Nelida's narratives exchanging her artistic performances for eggs and chickens in order to survive. Experiencing what Michel Maffesoli (2001) names as Dionysian effervescence, apart from a cultural industry of entertainment, it is possible to affirm that Caetana and her troupe manifest the desire for ways of subjectivities that scape
\end{abstract}

1 Título em inglês: The wandering impulse, the becoming-woman and the potency of $\operatorname{art}$ in $A$ doce canção de Caetana (caetana's sweet song). 
to the prevailing order of power institutions. Therefore, they stage the adventure of existence by means of an anomic experience characterized by deterritorialization, the constant movement and the possibility of becoming, according to the discussion developed by Gilles Deleuze and Félix Guattari (1997).

Keywords: Brazilian Literature; Nélida Piñon; Wandering; Becoming; Potency.

\section{INTRODUÇÃO}

A experiência da viagem como representação de uma descoberta existencial ou como processo simbólico de desterritorialização aparece como tema recorrente na literatura universal, traduzindo esteticamente os deslocamentos espaciais, culturais, o nomadismo do pensamento e o trânsito identitário de sujeitos desenraizados. A esse respeito, a obra da escritora contemporânea Nélida Piñon apresenta uma preocupação com as formas de manifestação de uma potência dos personagens socialmente considerados pobres, os quais escapam de uma condição de subalternidade a partir de uma vivência errante. Sobre a reincidência dessa temática na literatura da autora, recordemo-nos de alguns de seus romances como Fundador, $A$ república dos sonhos e $A$ doce canção de Caetana, esse último analisado de forma mais aprofundada ao longo do presente texto.

Em Fundador, publicado em 1969, a representação de um nomadismo circunstanciado por questões de miserabilidade pode ser percebida sobretudo na terceira temporalidade 
da narrativa por meio da história do protagonista Joseph Smith, que migra da Palestina, seu país de origem, para os Estados Unidos, acompanhando a família em busca de uma vida melhor. Na América, ele constitui a sua identificação num espaço de tensão entre a estrangeiridade do novo mundo e as máscaras do familiar simbolizadas pela manutenção de traços culturais da nacionalidade palestina dentro do lar americano. A república dos sonhos, lançada pela autora em 1984, é protagonizada por três personagens estrangeiros de origem espanhola e de uma estirpe humilde que chegam ao Brasil no início do século XX trazidos pelo desejo da aventura e pelo sonho de fazer a América. No desenvolvimento da trama, Madruga, Eulália e Venâncio vivem o triste paradoxo de pertencer a dois lugares, constituindo suas subjetividades a partir da experiência do deslocamento. Nessa mesma narrativa, como uma das histórias secundárias, desenrolamse também os dramas dos imigrantes portugueses pobres representados pelos personagens Viriato, um senhor que ganha a vida no Brasil fazendo frete, e sua esposa, dona Maria, uma lavadeira de roupas, os quais vivem no subúrbio carioca e que podem ser lidos como párias de uma sociedade global, semelhante ao que aponta o crítico a respeito do sujeito contemporâneo em condições de pobreza: 
Os pobres são anacrônicos de outra forma, agora no contraste com o espetáculo grandiloquente do pós-moderno, que os convocou nas suas terras para o trabalho manual e os abriga em bairros lastimáveis das metrópoles. [...] O fluxo dos seus novos habitantes é determinado em grande parte pela necessidade de recrutar os desprivilegiados do mundo que estejam dispostos a fazer os chamados serviços do lar e de limpeza e aceitem transgredir as leis nacionais estabelecidas pelos serviços de migração. (SANTIAGO, 2004, p.51)

A representação dos movimentos migratórios, a ficcionalização dos sujeitos desenraizados e os seus consequentes processos de construção e/ou desconstrução identitária são ainda tomados como matéria do romance A doce canção de Caetana, publicado em 1987, no qual a escritora associa o tema do nomadismo ao de uma potência dos pobres e à partilha do jogo teatral representados pelo grupo de teatro itinerante denominado "Os Romeiros" e pela própria protagonista Caetana, uma fracassada atriz mambembe que perambula pelo interior do Brasil, em pleno período da ditadura militar, como herdeira de uma arte funâmbula, legatária de uma vida de ciganos, e que aparece intercambiando seu fazer artístico por ovos ou galinhas, conforme assinala a própria personagem: 
- Nossa raça perambula pelo mundo sem endereço certo, desde muito antes da Idade Média, sempre perseguida pelo clero, pela nobreza, pelo frio, pela miséria. Aqui mesmo no Brasil, muitas vezes nos faltou dinheiro até para comer. Em certos povoados nos pagam com legumes, ovos e galinhas. (PIÑON, 1997, p.163)

Experienciando o que Michel Maffesoli (2001) denomina por efervescência dionisíaca, à parte de uma indústria cultural do entretenimento, é possível afirmar que Caetana e sua trupe manifestam o desejo por formas de subjetivação que escapam à ordem imperante das instituições de poder, investindo numa plena afirmação da ideia de potência como produção de vida, construção de ideias, como criação, no sentido postulado na obra dos filósofos franceses Gilles Deleuze e Félix Guattari, conforme demonstraremos.

Nessa leitura, adotaremos uma metodologia que tem como ponto de partida os estudos e pressupostos da Literatura Comparada em sua vertente mais atual, levando-se em consideração o dialogismo intrínseco ao discurso literário. Desse modo, no que se refere propriamente ao nosso objeto de leitura, abordaremos o romance de Piñon considerando a relação entre a literatura e a filosofia, procurando discutir de que maneira, em pleno contexto agonístico da ditadura militar, a personagem Caetana e a companhia de teatro 
da qual faz parte encenam a aventura da existência por uma vivência anômica caracterizada pela desterritorialização, pela movência constante, por um devir-mulher, que os impede de se ajustar às normas de uma organização social, fato que dificulta a solidificação de suas identidades.

\section{EXPRESSÕES DO DEVIR DE UMA IDENTIDADE RIZOMÁTICA E DO NOMADISMO}

Em $A$ doce canção de Caetana, os heróis da trama, representados pela protagonista e pelo grupo mambembe, são personagens sempre em via de constituir suas identificações por um permanente processo de deambulação. Tal fato thes consente, por vezes, emergirem no cenário social refratando a sua condição adversa de pobreza, a sua situação marginal de sujeitos perseguidos pelo 'clero, pela nobreza, pelo frio, pela miséria'. Por essa feita, no desenvolvimento da história, eles inspiram formas de resistência, em específico aquelas que dizem respeito à identificação do sujeito feminino, figurativizadas por meio da personagem Caetana, a qual encontra na arte teatral e no desejo de errância a possibilidade de devir-mulher, transgredindo estereótipos construídos ao longo dos tempos para a figura feminina.

A fim de que possamos demonstrar a coerência dessa leitura acerca da protagonista e de seus amigos saltimbancos, é oportuno recorrer, inicialmente, às discussões de Deleuze e Guattari, para quem: 
Devir é, a partir das formas que se tem, do sujeito que se é, dos órgãos que se possui ou das funções que se preenche, extrair partículas, entre as quais instauramos relações de movimento e repouso, de velocidade e lentidão, as mais próximas daquilo que estamos em vias de devir, e através das quais devimos. É nesse sentido que o devir é processo do desejo. (1997, p.67)

Consoante se nota, na acepção dos estudiosos franceses, o devir se constitui por uma zona de vizinhança, em que a interpretação do desejo se relaciona com aquilo que desterritorializa o sujeito, permitindo que ele, tomado por uma permanente vontade de partir e buscar em outras espacialidades aquilo que não lhe chega por meio de um modelo de vida fixado, se constitua por modos de individuação que escapam dos modelos pré-estabelecidos pelas instituições, como demostraremos, ocorre à personagem Caetana, ao tio Vespasiano e à trupe de teatro representada no romance.

Os estudiosos supracitados entendem ainda a ideia de devir num campo de multiplicidades que torna possível ao indivíduo estabelecer agenciamentos com o fora, com a diferença, possibilitando-Ihe construir novas subjetividades. É preciso compreender também que o devir seria, para essa concepção filosófica, um processo próprio do universo 
do minoritário, responsável por instituir uma dessemelhança em relação à forma padrão: “[...] o homem é majoritário por excelência, enquanto que os devires são minoritários, todo devir é um devir-minoritário. [...] Maioria supõe um estado de dominação, não o inverso" (DELEUZE \& GUATTARI, 1997, p.87). Desse modo, é que seria possível para Deleuze e Guattari falar num devir-animal, devir-criança, devir-mulher. A esse último, os dois estudiosos franceses dão um lugar de destaque, assinalando a necessidade do sujeito, para entrar em condição de devir, ter que experienciá-lo, visto que ele seria o responsável por abalar a forma imperante do indivíduo homem, tradicionalmente associada a uma imagem de masculino adulto, branco, ocidental e heterossexual.

Deleuze e Guattari reconhecem, no entanto, que, tal qual ocorre ao homem, também há uma forma mulher estabelecida pelas instituições de poder, como aquela instituída pelo patriarcado para o qual a figura feminina deveria ser fixada na representação de uma imagem de esposa submissa, boa mãe e dona de casa dotada de habilidades, como as de bordar e cozinhar. O devir-mulher passaria, então, por uma fuga desse modelo, tal qual se verifica na subjetivação da personagem Caetana, educada desde criança pelo tio Vespasiano, personagem igualmente mambembe, a partir de uma perspectiva que destoa de um padrão conservador: 
- Nada sei de como se educam as meninas brasileiras. Só sei que eduquei você para ser livre e dormir muito pouco. [...] - Peguei você praticamente nas águas do Nilo dentro de uma cestinha. Preferi eu mesmo educála que metê-la nessas casas com telhado e paredes envenenadas. Não queria que aprendesse a bordar e cozinhar. Acaso errei, menina? (PIÑON, 1997, p.110- 111)

Conforme se percebe pela fala do tio, a protagonista do romance compõe-se por uma representação que deslegitima as questões tradicionais de gênero advindas de uma sociedade patriarcal, provocando rupturas capazes de apontar para a produção de outros modos de vida. No caso de Caetana, o ato de devir-mulher aparece potencializado pelo fato de perambular "pelo mundo sem endereço certo" desde sempre. Somando-se a isso, destaca-se a educação que a personagem recebe do tio, a qual não é legitimada por qualquer instituição, nem segue padrões de um comportamento constituído por uma cultura nacional. Desse modo, em lugar de ser instruída para se tornar um sujeito submisso, dependente e recatado, Caetana é educada 'para ser livre', para se estabelecer enquanto sujeito na exterioridade do mundo e não no espaço da casa, tradicionalmente designado como natural para a figura feminina. 
Discorrendo a respeito do nomadismo e da pulsão da aventura, Maffesoli (2001) observa como teria sido próprio dos tempos modernos um compromisso de residência a partir do qual os sujeitos deveriam ser educados para o enclausuramento, tornando-se fixados. Nas palavras do estudioso, "Na verdade, foi característico da modernidade querer fazer tudo entrar na ordem, codificar e, stricto sensu, identificar." (MAFFESOLI, 2001, p.23). Contrariamente a essa perspectiva, o que se observa na fala do tio Vespasiano é a emergência de um desejo de errância com o qual ele educa a sobrinha, transgredindo uma identificação esperada para o sujeito feminino quase sempre traduzida pela insígnia da boa dona de casa dotada de aptidões domésticas, como as de bordar e cozinhar. Na criação dada à menina Caetana, o que se observa é que não se considera nem ao menos a noção de casa no seu sentido estrito com, "paredes" e "telhado", porque desde cedo a personagem aparece instigada à mobilidade, à pulsão migratória e à arte da deriva impulsionada, nesse caso, pelo fato de ter se tornado a atriz principal de um grupo de teatro que não recebe qualquer reconhecimento e que é dirigido pelo tio, para quem a casa é o próprio caminho. É aliando o arquétipo do êxodo à vocação artística, inclusive, que a personagem é apresentada ao leitor: 
Tudo que quis, desde que abandonou o berço, foi representar. Ela vem de família de artistas. Vespasiano que a educou, orgulhavase de jamais ter tido uma casa montada. Era um nômade. Levava os pertences nas costas como caramujos. Igual a nós, que nem sabemos às vezes em que buraco do Brasil nos metemos. (PIÑON, 1997, p.122, 123)

Nota-se, no caso de Caetana e da companhia de atores saltimbancos da qual ela faz parte, uma associação entre uma mobilidade inerente à dinâmica teatral e a necessidade de infinito traduzida pela natureza errante de Vespasiano, a qual aparece manifestada por uma constate deambulação indispensável para o seu ofício de artista mambembe, em que os sujeitos se deslocam de uma comarca para outra, com o propósito de realizarem a sua encenação, carregando consigo os pertences nas costas. É preciso considerar ainda que no sentimento de orgulho de Vespasiano, o mesmo que pode ser encontrado em Caetana ao longo da narrativa, desponta a percepção de um nomadismo passional, semelhante àquele de que nos fala Maffesoli (2001, p.129) e que apareceria "[...] como meio de escapar da esclerose mortífera do instituído".

Por meio dessa leitura, a errância seria representada em A doce canção de Caetana como uma espécie de potência, permitindo a Caetana e sua trupe engendrar formas 
de sobrevivência para além de uma ordem estabelecida. Essa interpretação pode ser comprovada ao longo do enredo, na medida em que a identificação da protagonista vai sendo formulada em contraste com a de outros personagens, sobretudo com a de alguns moradores da localidade de Trindade, uma pequena cidade na qual a atriz havia aportado com a companhia mambembe há pelo menos vinte anos e para a qual estava em vistas de retornar, consoante relata a personagem em carta dirigida aos habitantes do lugar:

Deixei Trindade de trem numa sexta-feira muito antiga. Lembro-me bem de que chovia. Logo que o apito do trem deu o sinal de partida, esforcei-me em enxergar através dos vidros sujos da janela. Não vi senão o aguaceiro que confundiu a paisagem com os que ficaram estatelados na estação e que, diferente de mim, jamais sairiam de Trindade. Agora, porém, chegou a hora de voltar. Retorno, pois, neste mês de junho, e pelo mesmo trem que me levou. Escolhi sexta-feira para ter a ilusão de que não se passaram vinte anos. Quanto ao resto, é aguardar. A vida é quem nos dá o recado no canto do ouvido. Assinado, Caetana. (PIÑON, 1997, p.55)

Na correspondência enviada pela atriz aos residentes de Trindade, relatando acerca do seu retorno ao lugarejo, a personagem assinala uma diferença que será percebida pelo leitor atento ao longo de toda a trama: enquanto Caetana 
constrói sua subjetivação a partir de um permanente processo de desterritorialização, os habitantes da cidade, seguindo vocação contrária, investem numa forma de vida fixada nos limites da localidade, por isso "jamais sairiam de Trindade".

A relação de antagonismo instaurada por uma comparação entre essas duas formas de vida distintas poderia ser lida a partir de uma associação com outra discussão deleuze-guattariana que se refere à ideia de rizoma e à noção de árvore-raiz. Pensada numa analogia com os postulados da botânica, a primeira ideia desponta como conceito chave para a filosofia de Deleuze e Guattari, que afirmam que "O rizoma nele mesmo tem formas muito diversas, desde sua extensão superficial ramificada em todos os sentidos até suas concreções em bulbos e tubérculos" (DELEUZE \& GUATTARI, 1995, p.15). Numa aproximação com essa noção, a identidade da protagonista estaria ligada à imagem do rizoma, caracterizando-se por uma subjetividade não fixada, desdobrável, com possibilidades de agenciamentos com a exterioridade, com aquilo que se encontra para além das fronteiras da localidade de Trindade, em acordo com o que formulam os estudiosos a partir dos princípios de conexão e heterogeneidade que caracterizam o conceito: "[...] qualquer ponto de um rizoma pode ser conectado a outro e deve sê-lo" (DELEUZE \& GUATTARI, 1995, p.15). 
Por outro lado, a identidade dos que ficaram "estatelados na estação" e "jamais sairiam de Trindade" poderia ser traduzida, de acordo com a mesma corrente filosófica, pela imagem da árvore-raiz caracterizada por formas de vida fixadas e por preceitos institucionalizados, como se verifica, sobretudo, no decorrer do romance, pelo comportamento dos personagens Polidoro, de quem a atriz fora amante, e sua esposa dona Dodô, figurativizada na história como uma mulher conservadora, para quem a defesa da própria classe e dos valores tradicionais da família aparece em primeiro plano, por isso se orgulha de dizer: "—-Sou mulher decente. Não quero ser confundida com essas putas à solta em Trindade" (PIÑON, 1997, p.353).

A identificação a que Dodô deseja se associar é a de um feminino codificado pela sociedade patriarcal para a qual a noção de decência sujeita a mulher a um modelo padrão de esposa e mãe do qual parece vergonhoso a personagem se afastar, porque correria o risco de "ser confundida" com as putas do lugar, contra as quais ela exercerá, inclusive, uma prática política e um policiamento moral, que passa por uma vontade de silenciamento desse tipo de alteridade. A personagem Dodô, dessa maneira, será representada como o oposto de Caetana. Por isso que, não por acaso, será ela que, se valendo 
do prestígio e da fortuna da família, tomará o delegado do lugar como aliado e dividirá a cidade entre aqueles que a apoiam e os que estarão ao lado da atriz no episódio de seu retorno ao palco do teatro Iris:

Trindade está dividida em dois grupos, disse Balinho, apressado. - O primeiro defende Caetana e prepara as roupas, as jóias e as emoções para a estréia. $O$ outro é de formação recente. Torce por dona Dodô e afia as unhas em pedra-pome. Vejam vocês que essa senhora, após a inauguração do busto de seu Joaquim, foi posta a par pela própria filha de que Caetana, de volta à cidade, se instalou no Palace. Foi um custo conter a ira da mulher. (PIÑON, 1997, p.280)

De acordo com o que vamos percebendo, diferente do que ocorre à protagonista Caetana, não há na esposa de Polidoro qualquer possibilidade de devir-mulher, visto que essa última personagem aparece fixada no seu mundo pequeno burguês, preocupada em defender o seu ideal de família, em amealhar bens e não colocar em risco a fortuna de sua parentela, que poderia ser dividida como consequência de uma possível separação: "A abundância da mesa de Dodô não visava saciar a fome alheia. Exibia tão-somente a força do dinheiro. Como uma missionária a arregimentar pagãos e anexar terras férteis, Dodô acumulava dinheiro e pertences para regalar às filhas o produto de tanto empenho" (PIÑON, 1997, p.318). 
Entre Caetana e Dodô, duas mulheres de identificações tão contrastantes, desponta a figura de Polidoro Alves. Esposo de uma e ex-amante da outra, ele é descrito quase sempre como um sujeito dominador, de coração endurecido pelas lições que recebera como herança paterna, ou ainda como um fazendeiro rico, oriundo de uma descendência abastada, fato que lhe permite exercer determinada autoridade sobre os integrantes da família e os moradores de Trindade. Por conta de sua personalidade autoritária será, portanto, ele e não propriamente dona Dodô, quem aparece representado como o verdadeiro antagonista de Caetana, tentando a todo custo despotencializá-la, afastando-a de sua vocação teatral e de sua pulsão da errância, segundo se atesta na seguinte passagem literária: "animava-o a lembrança de haver-lhe proposto no passado que ficasse a seu lado. Propiciava-lhe casa com quintal, talheres, roupa de cama, despensa farta, tudo que a fizesse esquecer as agruras da vida teatral (PIÑON, 1997, p.178).

O que vem à tona no embate que se trava entre Polidoro e Caetana é uma dialética inconciliável representada, de um lado, pelo desejo de aprisionamento que o homem direciona em relação à mulher, e, de outro, pela aspiração de liberdade que ela não para de potencializar. Nesse caso, o que ele tenta 
a qualquer preço é reorganizar as vontades da atriz dentro de uma realidade medíocre que passa longe de sua vocação para a arte teatral e, pela oferta da casa, ainda mais distante de sua pulsão da errância. Há em Polidoro uma espécie de esforço semelhante àquele de que nos fala o sociólogo francês e que seria colocado em prática pelas sociedades tradicionais para as quais:

Há um empenho inicial para estabelecer um cerco em torno do errante, daquele que se desvia, do marginal, do estrangeiro, depois para domesticar, para estabelecer numa residência o homem sem condição de nobreza, assim privado de aventuras. (MAFFESOLI, 2001, p.82)

Distintamente ao que sucede à atriz, ao tio Vespasiano e ao grupo mambembe, para os quais o aberto do mundo aparece como um convite permanente à partida, Polidoro afirma sobre si: "- O mundo para mim cabe dentro deste município, disse ele, os olhos postos num horizonte imaginário. - Há vinte anos não viajo." (PIÑON, 1997, p.61). Num sentido mais amplo, a afirmação do homem não traduz apenas uma limitação física de um corpo condenado ao assentamento na interioridade provinciana do município, mas denota principalmente uma ideologia que se caracteriza por uma visão limitadora da vida, por uma falta de potência 
que o leva a se fechar nos limites fronteiriços de um pensamento conservador, com o qual ele mormente busca territorializar Caetana, transformando-a em sua esposa pela promessa de uma casa com "quintal", "talheres" e "roupa de cama".

Dessa maneira, Polidoro tenta subordinar Caetana a uma realidade identitária consagrada por uma instituição patriarcal para a qual o destino da mulher deveria passar necessariamente pelo espaço da casa, como se ratifica em outra passagem do romance: "vinte anos antes, após entregar a carta, Polidoro oferecera-Ihe uma casa mobiliada em troca de viver em Trindade. E garantira-Ihe igualmente uma pensão vitalícia" (PIÑON, 1997, p.189). Na oferta que o homem dirige à mulher, é preciso destacar não aquilo que aparece como uma suposta beneficência, um lar acompanhado por uma quantia em dinheiro, mas o que ele busca retirar dela: o estranhamento de um corpo sensível para o qual a deambulação é antes de qualquer coisa uma celebração da vida, que se potencializa ainda mais pelo escapismo lúdico do jogo teatral. Isso não implica em dizer que não haja por parte de Caetana e de todos os demais integrantes do grupo de funâmbulos uma consciência relativa às dificuldades de uma vida permanentemente em trânsito, ainda mais quando 
essa aparece marcada por uma condição de miserabilidade, tal qual assinala a própria personagem: "- Carregamos a miséria nas costas. Nossa fortuna consiste em baús de areia. Se vendermos tudo que aí está, não dará para pagar um prato de comida. [...] Caetana protestou contra a pobreza que os perseguia" (PIÑON, 1997, p.112-113).

Há toda uma discussão teórica e crítica desenvolvida no âmbito das ciências humanas e sociais a respeito da relação entre os movimentos migratórios e as difíceis condições dos sujeitos que são obrigados a abandonar a sua pátria em busca de uma vida melhor. Essa não é, nem de longe, uma matéria de exclusividade da literatura. O crítico literário e ativista palestino Edward Said (2003, p.47), discorrendo a respeito das condições do exílio, lembra que “[...] nossa época, com a guerra moderna, o imperialismo e as ambições quase teológicas dos governantes totalitários, é com efeito, a era do refugiado, da pessoa deslocada, da imigração em massa". Nesse caso, a deambulação é certamente um drama contemporâneo, mas pode ser lida também como uma forma de potência contra aquilo que denota essa temporalidade agônica a qual se refere o estudioso, possibilitando ao indivíduo nômade escapar de posturas autoritárias de poder, investindo em modos de subjetivação por meio dos quais 
não aceitam a domesticação de seus corpos, tal qual ocorre à protagonista do romance nelidiano na sua relação com Polidoro. De acordo com o texto literário,

Polidoro [...] não se conformava com Caetana, que renunciara à sua tutela para entregar-se a andarilhos que talvez a possuíssem agora, sem respeitar as marcas da volúpia deixadas por ele em seu corpo. Não podia suportar a idéia de que ela fora feliz sem ele. (PIÑON, 1997, p.64)

O inconformismo do personagem masculino, representado pelo fato de não suportar a ideia da felicidade do outro, nesse caso, é o mesmo que não admitir a produção de outros modos de vida que divergem daqueles hegemonicamente estabelecidos. Por esse motivo, Polidoro insiste numa tentativa de apagamento da diferença com suas indagações em forma de repreensão, censurando a todo instante o grupo de teatro itinerante e a educação que o tio Vespasiano oferece à Caetana:

- Que tio é esse que em vez de aconselhar a sobrinha a aceitar uma casa posta em Trindade, onde teria um pomar com árvores frutíferas, um galinheiro, ovos frescos pela manhã, e dinheiro no banco para comprar o que lhe fizesse falta, corrompeu o espírito da sobrinha com o intuito de fazê-la andar por esse Brasil afora, junto com uns ciganos condenados pela miséria e pela ilusão esfarrapada? Aonde irão um dia morrer? 
Ou não quer para Caetana um fim tranquilo, ao lado de um homem que lhe cerre os olhos e lhe providencie uma sepultura cristã e digna? Chega de sonhos, seu Vespasiano. 0 senhor não tem pejo de destruir uma vida? disse Polidoro, dias antes da fuga do grupo. (PIÑON, 1997, p.131)

Consoante novamente se observa, Polidoro compreende que uma identificação de felicidade voltada para o sujeito feminino deve passar necessariamente pelo espaço de uma casa abastada com frutas, ovos e dinheiro para as necessidades, como já demonstrado pela leitura de outras passagens do romance. Em contraposição ao que pensa o examante, Caetana é instigada pelo tio e pela sua experiência funâmbula ao desejo de devir e de heterogeneidade, que se opõe ao estável e a uma vida sem grandes aconteceres nos limites da medíocre territorialidade de Trindade. Tanto é assim que por mais de uma vez não cede aos apelos do homem, não se deixa fascinar pelos bens materiais que ele Ihe oferta quase como se Polidoro estivesse disposto a comprá-la, fazendo questão de lembrar a ela, a Vespasiano e aos demais atores saltimbancos, a miséria que os acompanha em suas andanças pelo Brasil.

Todavia, ainda que a pobreza seja para eles uma realidade, por mais de uma vez o grupo foge de Trindade, 
não admitindo que o homem, numa tentativa de impedi-los de se realizar como artistas, proponha-Ihes o cancelamento do sonho, o que para a atriz apareceria como uma falta grave, pois conforme observa o narrador "- Caetana tinha a mania de consertar o que Ihe parecia feio. Como artista, não se conformava com a realidade" (PIÑON, 1997, p.63). A possível razão do inconformismo da atriz com a realidade poderia estar relacionada com uma percepção limitadora de um mundo real institucionalizado, o qual Polidoro insiste em lhe ofertar como uma espécie de presente, e que apareceria em contraposição à potência da arte capaz de transportá-la para outros universos. Nesse sentido, a errância representada em A doce canção de Caetana não seria apenas aquela de um corpo físico que deambula de comarca em comarca instigada pelo espetáculo circense, mas também outra que aparece manifestada pela potência da arte.

\section{EXPRESSÕES DO PODER E DA POTÊNCIA}

Visando melhor compreender a identificação dos personagens Caetana e Polidoro, retomemos a obra de Deleuze e Guattari para problematizarmos a relação entre as noções de poder e potência, enquanto conceitos que, embora se assemelhem, são pensados pelos dois filósofos de maneira contrastante e serão relacionados aqui a outra discussão 
deleuze-guattariana relacionada ao comportamento do aparelho de Estado e da máquina de guerra. Tal relação se torna necessária visto que a ideia de poder para os estudiosos supracitados aparece associada às instituições, ao aparelho de Estado, manifestando-se por uma ação autoritária, por coação. Assim, o representante do poder se utilizaria de todos os recursos possíveis para dominar o seu oponente, procurando se apropriar do outro para torná-lo seu escravo. Nessa empreitada, seria importante, sobretudo, capturar a subjetividade alheia, apreendê-la dentro de uma interioridade reconhecível e que se possa administrar. Assim,

a esse respeito, os filósofos destacam que "O Estado é a soberania. No entanto, a soberania só reina sobre aquilo que ela é capaz de interiorizar, de apropriar-se localmente" (DELEUZE \& GUATTARI, 1997a, p.23). Esse modo de agir da instituição estatal explicaria o porquê de Polidoro buscar a todo instante sociabilizar Caetana no espaço da cidade, no território fechado da casa, sob a sua guarda, em lugar de aceitar a sua pulsão da errância.

Ao contrário do poder, a noção de potência, para a mesma corrente filosófica, aparece relacionada à máquina de guerra, caracterizada especialmente por sua exterioridade: "Quanto à máquina de guerra em si mesma, parece efetivamente 
irredutível ao aparelho de Estado, exterior a sua soberania, anterior ao seu direito: ela vem de outra parte" (DELEUZE \& GUATTARI, 1997a, p.12). Pensada por essa associação, a potência surgiria, então, como uma transgressão aos padrões conservadores que não suportam a sua emergência, a sua plena afirmação de liberdade traduzida por uma permanente vontade de agenciar com o fora, como faz Caetana ao recusar a tutela de Polidoro, "para se entregar a andarilhos", deixando claro para o homem a sua mundanidade.

É preciso chamar a atenção para o fato de que em todo o seu Tratado de nomadologia, Deleuze e Guattari destacam a ligação entre a máquina de guerra e o fenômeno da deambulação. Para os dois filósofos franceses, “A máquina de guerra é a invenção dos nômades [...] A existência nômade efetua necessariamente às condições da máquina de guerra no espaço." (DELEUZE \& GUATTARI, 1997a, p.50). Nessa linha de raciocínio, seria legítimo pensar a identificação da protagonista Caetana, e de todo o grupo de teatro mambembe, como metamorfose de uma máquina de guerra, que se opõe formalmente ao aparelho de Estado.

Seguindo o mesmo pressuposto, também seria coerente relacionar a identificação de Polidoro àquela das instituições, bastando destacar que no comportamento do homem 
se explicita o modo mais absoluto e triste de poder: aquele que passa necessariamente pela impotência do outro, pelo desejo de tornar a alteridade nula, impedindo-a de se realizar enquanto sujeito de sua própria existência, por isso que, como consequência das escolhas da mulher, o personagem acaba não suportando 'a ideia de que ela fora feliz sem ele'.

O embate entre poder e potência pode ser ainda discutido a partir de uma leitura do contexto político do país na década de 1970, em que se desenrolam as ações do retorno de Caetana, depois de 20 anos, à cidade de Trindade. Considerando esse momento da história nacional, é preciso atentar por fim para outras formas institucionalizadas de manifestação de poder que apareceriam aludidas ao longo da trama por meio de referências à ditadura militar, em específico ao governo do general Médici. O regime de coerção imposto à nação pela presença dos militares no poder atuaria, de certa maneira, como um campo ideológico ao qual os setores ultraconservadores da localidade fictícia de Trindade se aliariam, visando eliminar a diferença por meio de uma prática opressora caracterizada pelo signo da violência, semelhante àquela desenvolvida à época nos grandes centros do Brasil:

As notícias alvissareiras naquela semana bafejavam o presidente Médici, cujo sobrenome, de príncipe renascentista, inundava o país com o esplendor do ouro 
e do sangue. - Dizem que há tortura no Brasil. Dão choques nos testículos e enfiam garrafas inteiras no rabo. (PIÑON, 1997, p.279)

A doce canção de Caetana, nesse sentido, representaria uma alegoria da situação de censura e repressão que, em tempos agônicos, assolava o estado brasileiro e que, em Trindade, atingiria uma série de sujeitos mais suscetíveis a um policiamento moral, como seria o caso das velhas prostitutas do lugarejo e da própria Caetana. Essa última, depois de perambular pelos lugares mais distantes do país sem encontrar a glória almejada, resolve, à beira da velhice, reencontrar o ex-amante para cobrar a ele uma antiga promessa: fazê-la pelo menos uma única vez uma atriz reconhecida, tornando possível o seu sonho de encenar no teatro da cidade a ópera La traviatta, na qual viveria o papel de Maria Callas.

O que a atriz talvez não esperasse é que, mesmo sendo ajudada pelo poder econômico de Polidoro, pelas colegas prostitutas que reencontra na cidade e que são cognominadas por três graças, e por uma antiga amiga cafetina denominada Gioconda, ela e os integrantes do grupo mambembe teriam que enfrentar as forças conservadoras da cidade, como aquela figurativizada pelo delegado Narciso, dispostas a impedi-la de se consagrar ao menos uma vez como uma grande artista: 
Entretidos na conversa, um forte ruído atraiu-Ihes a atenção. Era Narciso, que batia a coronha do revólver contra uma cadeira. - Vamos acabar com esta farra! [...] - Vim cumprir meu dever, disse com inabalável decisão. [...]. Tenho ordem de fechar o teatro. Sua instalação é precária e infringe as posturas municipais. (PIÑON, 1997, p.310)

O delegado Narciso simboliza a expressão de um poder institucionalizado ligado a um aparelho de Estado que, no período da ditadura, se constituiu por meio de uma atuação repressora, como a que o personagem busca exercer sobre o grupo de artistas que ocupa o teatro de Trindade. Assim, ele se vê como um sujeito que tem deveres a cumprir, um representante da ordem, enquanto Caetana e os demais atores saltimbancos representam justamente o contrário, sendo responsabilizados por instaurar a farra. Esse exercício nefasto do poder, que na cena supracitada se revela nas ações do delegado Narciso, alcança representação máxima ao final da história, durante o episódio da invasão do teatro pelas forças tradicionais da cidade, as quais, alegoricamente, exprimem o contexto de coerção que atuava à época no Brasil:

Tudo começou um pouco antes de terminar o primeiro ato. Eu estava na primeira fila. Tão comovido que não me passou pela cabeça que Narciso, levado por um impulso insano, 
fosse usar a porta dos fundos para silenciar Balinho com um ato criminoso. (PIÑON, 1997, p.384-385)

Em certo sentido, a obra nelidiana reaviva esteticamente o drama de uma série de artistas e intelectuais vítimas de um sistema que não suporta a emergência da alteridade e que acaba atuando sobre ela por meio da censura e de uma violência física que visa enquadrá-la dentro de normas preestabelecidas e, em última instância, silenciá-la. Seguindo essa interpretação é que Narciso desponta na cena em análise como um legítimo representante do poder, tentando pelo uso da força impedir que Caetana, Balinho e os demais atores mambembes se manifestem por meio de sua vocação teatral. Todavia, ainda que sorrateiramente o delegado invada o teatro, tentando a todo custo despotencializar Caetana e sua trupe, a mulher insiste em proclamar o seu destino de artista, mesmo diante da atitude funesta e autoritária do delegado:

Não mudaremos o nosso destino de artistas por conta desses capatazes. [...] - Quem são eles para nos derrotar, se a própria vida já se encarregou dessa tarefa! [...] - Bem-vindos sejam os inimigos! Inclusive o delegado Narciso. Enquanto existir a arte, a casa é de todos. (PIÑON, 1997, p.313)

Dessa maneira, ao longo de toda a narrativa o que observamos é uma reafirmação de uma potência da arte 
por parte de Caetana, como um exercício de construção de formas de devir que se constituem por um entrelaçamento entre a dinâmica do jogo teatral e um corpo em trânsito que escapa e inspira resistência, desestabilizando um ideal de vida fixado e com pretensões de homogeneidade. Por isso é que, ao final da história, ela e os demais atores mambembes mais uma vez investem numa estratégia de fuga como forma de sobrevivência: "Caetana eclipsara-se do camarim. Enquanto discutiam, ela levara consigo as roupas e as jóias falsas. $\mathrm{O}$ toucador estava nu. [...] - Eles fugiram de novo. Como há vinte anos." (PIÑON, 1997, p.392).

\section{CONSIDERAÇÕES FINAIS}

No desenvolvimento deste artigo, realizamos uma leitura crítica do romance $A$ doce canção de Caetana, da escritora Nélida Piñon, destacando o processo simbólico da desterritorialização representado pela trajetória de vida da protagonista e pela experiência mambembe dos demais personagens que compõem o grupo de teatro itinerante do qual a atriz faz parte. Constatamos que, em Caetana, a pulsão da errância aparece como produção de outros modos de subjetivação, como uma estratégia política de sobrevivência que, associada à potência da arte, permite a ela experienciar formas de devir que rasuram um modelo de comportamento 
instituído pela tradição, em específico para o sujeito mulher, quase sempre educado para se identificar com o espaço recluso da casa.

Desse modo, a experiência de migração, representada por uma vida permanentemente em trânsito pelos rincões do país, não aparece associada, na narrativa nelidiana, necessariamente a um drama, a uma perda ou a qualquer sentido negativo, mas como uma forma de celebração de uma existência que se realiza como performance e que contribui para fissurar um sistema social que visa a todo instante investir na fraqueza da alteridade como exercício absoluto de dominação. No desejo intenso e sempre presente de compartilhar a sua arte, mesmo enfrentando condições adversas exemplificadas por uma realidade de pobreza e de coação, Caetana almeja realizar a partilha do sensível, demonstrando a todo instante que a opção por uma vida liberta é que representa a plena afirmação da potência.

\section{REFERÊNCIAS}

DELEUZE, Gilles; GUATTARI, Félix (1995). Mil platôs: capitalismo e esquizofrenia. 1. Aurélio Guerra Neto e Celia Pinto Costa (Trad.). São Paulo: Editora 34.

(1997). Mil platôs: capitalismo e esquizofrenia. 4. Suely Rolnik (Trad.). São Paulo: Editora 34.

(1997a). Mil Platôs: capitalismo e esquizofrenia. 5. Peter Pál Pelbart e Janice Caiafa (Trad.). São Paulo: Editora 34. 
MAFFESOLI, Michel (2001). Sobre o nomadismo: vagabundagens pósmodernas. Marcos de Castro (Trad.). Rio de Janeiro/São Paulo: Editora Record.

PIÑON, Nélida (1997). A doce canção de Caetana. Rio de Janeiro/São Paulo: Editora Record.

(1998). Fundador. Rio de Janeiro/São Paulo: Editora Record.

(1997). A república dos sonhos. Rio de Janeiro/São Paulo: Editora

Record.

SANTIAGO, Silviano (2004). O cosmopolitismo do pobre: crítica literária e crítica cultural. Belo Horizonte: Editora UFMG.

SAID, Edward (2003). Reflexões sobre o exílio e outros ensaios. Pedro Maia Soares (Trad.). São Paulo: Companhia das Letras.

Roniê Rodrigues da Silva é Pós-doutorando (PNPD/CAPES) no Programa de Pós-graduação em Literatura e Interculturalidade da Universidade Estadual da Paraíba (UEPB). Doutor em Literatura Comparada pela Universidade Federal do Rio Grande do Norte (UFRN). Docente na Universidade do Estado do Rio Grande do Norte (UERN). Mestre em Letras pela UFRN. SILVA, R. R. A cartografia da errância e o resgate das memórias subterrâneas no romance Fundador de Nélida Piñon. REVISTA ITINERÁRIOS, 44, p.113-124, 2017. SILVA, R. R.; CASTRO, N, M, S. O conto rodrigueano e constituição do corpo sem órgãos: interfaces entre literatura e filosofia. REVISTA LETRAS RARAS, 7, p.75-88, 2018. E-mail: rodrigopinon2014@gmail.com 